\title{
Balkanologie
}

Revue d'études pluridisciplinaires

Vol. $15 n^{\circ} 2 \mid 2020$

Pour une approche socio-historique de l'action collective dans les Balkans

\section{Workers' Struggles in Post-Socialist Slovenia: Between Trade Union Strategies and Worker Stratification in the Workplace}

Les luttes ouvrières dans la Slovénie postsocialiste: stratégies syndicales et stratification des travailleurs sur leur lieu de travail

\section{Maja Breznik and Boris Mance}

\section{(2) OpenEdition}

\section{Journals}

\section{Electronic version}

URL: http://journals.openedition.org/balkanologie/2592

DOI: 10.4000/balkanologie.2592

ISSN: 1965-0582

\section{Publisher}

Association française d'études sur les Balkans (Afebalk)

\section{Electronic reference}

Maja Breznik and Boris Mance, "Workers' Struggles in Post-Socialist Slovenia: Between Trade Union Strategies and Worker Stratification in the Workplace", Balkanologie [Online], Vol. 15 n $^{\circ} 2$ | 2020, Online since 01 December 2020, connection on 23 April 2021. URL: http://journals.openedition.org/ balkanologie/2592 ; DOI: https://doi.org/10.4000/balkanologie.2592

This text was automatically generated on 23 April 2021.

(c) Tous droits réservés 


\title{
Workers' Struggles in Post-Socialist Slovenia: Between Trade Union Strategies and Worker Stratification in the Workplace
}

\author{
Les luttes ouvrières dans la Slovénie postsocialiste: stratégies syndicales et \\ stratification des travailleurs sur leur lieu de travail
}

Maja Breznik and Boris Mance

\section{AUTHOR'S NOTE}

\section{Acknowledgements}

The authors gratefully acknowledge the helpful comments on earlier drafts of this paper from the editors Catherine Samary and Sarah Sajn. We are also grateful to the anonymous reviewers for their valuable suggestions.

\section{Funding}

Maja Breznik's work is supported by the Slovenian Research Agency (ARRS) [grant number J5-9335 and 6037-24/2016/87].

1 In their book Capitalist Diversity on Europe's Periphery, Dorothee Bohle and Béla Greskovits draw attention to the specificity of Slovenia's socio-economic development in (post-socialist) transition. ${ }^{1}$ Comparing degrees of privatisation, compensation for social costs, and the influence of organised labour on policymaking, they propose three types of capitalism: a neoliberal type in the Baltic states, an embedded neoliberal type in the Visegrád countries (plus Croatia), and a neocorporatist type in Slovenia.

The system of tripartite negotiations between trade unions, business organisations and the state, the authors believe, was capable of determining socio-economic development quite independently of external pressures in the aftermath of Slovenia's departure 
from the Yugoslav Federation (in 1991). While trade unions in Croatia, Bulgaria and Romania also showed high mobilisation capacity and managed to form tripartite bodies in the early 1990s, it was only the Slovenian "social partners" that turned it into a permanent negotiating institution. This system of coordination led to stable economic results for over a decade and considerably balanced the social development by relying on internal forces and the legacy of workers' self-management. Bohle and Greskovits stress that "the Yugoslav legacy of workers' self-management added a level of participatory decision making unknown in other East Central European countries, and developed it into a system of negotiated industrial relations" 2 - the "neocorporatist model".

3 According to Lucio Baccaro and Chris Howell, ${ }^{3}$ similar forms of collective bargaining were also in use in certain Western European countries like Italy, Sweden and Ireland, to control troubles while generating social change. However, notwithstanding the different context and scenario in each of these countries, such social changes led to a crisis of political "representation" while, in the long run, the concessions made by the trade unions more or less eroded labour rights: collective agreements were increasingly minimalistic; the number of derogations from general agreements rose; and trade union membership continued to shrink as did the number of employees under a collective agreement. Baccaro and Howell interpret these processes as the result of a long-term convergence of industrial relations in the neoliberal direction. Indeed, the Chicago economic school (including Milton Friedman and Gary Becker) and historical promoters of the free market and neoliberal order were opposed to what they called the "privileged protections" given to trade unions. They claimed that protections distorted a "well-functioning labour market," and that the higher wages received by trade union members increase unemployment and lower wages in nonunionised sectors.

4 The transformation of labour/capital relations has entailed multiple dimensions in Slovenia. This article does not aim to analyse them all, but to shed light on how Slovenian trade unions' strategies and membership have evolved since the end of socialism, with a specific interest in the stratification of workers. This is consistent with both historical and recent research on divisions within the "working class" recognising that, to paraphrase Emmanuel Terray, all proletarians are wage workers (in a legal sense), yet not all wage workers are proletarians. ${ }^{4}$ Eric Hobsbawm's historical research showed the socio-economic cleavages of the working class, with a division between the labour aristocracy and the labouring poor. ${ }^{5}$ The term labour aristocracy, in Hobsbawm's usage, refers to two crucial historical controversies. The first, from the nineteenth century, concerned trade unions made up of a small stratum of skilled workers, artisans and middlemen who enjoyed much better working conditions and (directly or indirectly) benefited from co-exploiting the labouring poor. By defending their privileges, these trade unions came into conflict with the general trade unions fighting for the rights of unskilled workers. The second controversy drew on the old (post-1917) Marxist critique that the "labour aristocracy" is responsible for the reformism of unionism and of certain political (socio-democratic) parties. ${ }^{6}$ In the twentieth century, debates on the existence of a labour aristocracy and the stratification of workers continued. Research into the contemporary working class in the 1970s and 1980s revolved around the term petty bourgeoisie. While some authors, like Nicos Poulantzas, related it to unproductive labour (as opposed to productive labour), ${ }^{7}$ others related it to the "superiors" who receive a share of the surplus value 
that capital extracts from workers. ${ }^{8}$ Recent research by Duménil and Lévy looks at a particular group of wage workers - management - as a new social class that extracts surplus labour from workers by means of wage inequalities. ${ }^{9}$ Despite differences in the authors' perspectives and their concepts, they all point to unequal relations among various groups of wage workers.

5 Most of these authors analyse the political orientation of the groups they identify. The analyses by Baudelot, Establet and Malemort ${ }^{10}$ help in understanding the different (even contradictory) political effects produced by the petty bourgeoisie in various stages of capitalist development. However, our research goes beyond the political consciousness of one specific social group by questioning the articulation of the various "political positions" held by groups within the working class. With this aim in mind, we analyse different expectations of workers in the workplace and within trade unions using the concept of the "technical" and "political" composition of the labour force. These two notions were developed by the Italian Operaismo from the Marxist concepts of the organic composition of capital, its technical and value composition. ${ }^{11}$ The technical composition of the labour force is understood as a particular division of labour in the labour process, and of the separation of execution from control and planning. As such, it determines the conditions for the labour force's political articulations, including the differences (conflicting interests, tensions) among groups of wage workers. Still, the political composition is also influenced by many external factors; namely, political, social, historical and cultural. ${ }^{12}$

6 Adopting the concepts developed by Operaismo and relying on our case study, the article focuses on the relationship between a trade union and its membership, trade unions' strategies and the composition of trade union membership, as well as how workers perceive trade union activities. We ask who are trade union members: privileged core workers, the labour aristocracy or unskilled workers? Who are the biggest supporters of trade unions? What do they expect in return for their support? Which differences exist among various groups of workers, between unionised and nonunionised workers? How are these groups connected to trade union strategies?

7 The first section of the article analyses the evolution of Slovenian trade unions from the socialist period to the present, highlighting three major strategies. After stressing the main features of trade unions during the self-management system, trade unions are shown to have evolved from a "social partnership" to "class-based unionism" and then to "economic unionism." The article then proceeds to a case study where in the second section of the article the stratifications among workers (expressing the "technical composition of labour") in three large companies where we conducted the research are examined. In the third section, we approach the political composition of workers as reflected in trade union membership and workers' expectations of trade unions. Finally, in the conclusion, we comment on the main results, the limits and possible further development of our research.

8 The case study builds on data collected in the framework of a research project we carried out in 2013 and 2014. It allows a glimpse behind the factory walls of three Slovenian companies: $:^{13}$ a state-owned paper company, ${ }^{14}$ a publishing company in domestic private ownership, and a printing company owned by a multinational company. The research was commissioned by a confederation of trade unions established in the early 1990s after a split from the Association of Free Trade Unions of Slovenia (ZSSS). The confederation selected companies in which it was active. Although 
we had no say in this selection of the cases, one positive aspect was that the confederation organised full access to the company premises for us. To ensure a thorough investigation, the research integrated several research methods: document analysis, focus groups, interviews and survey. Analysis of internal and publicly accessible documents provided the macro context of workers' stratification. The study of the internal documentation on work systemisation and collective agreements within the branch of a particular company was complemented with publicly available documents and published data. ${ }^{15}$ The triangulation of quantitative and qualitative methods yielded a thorough insight into working relationships. A survey among the population of workers was conducted in all three companies between November 2013 and February 2014. Out of a total of 1,285 employed workers, 827 10-minute-long paper questionnaires were collected; 480 ( 80 per cent response rate) from workers in the paper company, 257 (59 per cent response rate) in the publishing company, and 90 (69 per cent) in the printing company.

9 To investigate the management and trade union perspectives, we made 15 semistructured interviews: 9 with members of executive boards and human resources representatives, 4 with trade union representatives, and 2 with representatives of the work councils. ${ }^{16}$ Research outcomes of the quantitative and qualitative analysis were further complemented through presentations and discussions within the three focus groups in which employees from all company departments participated. ${ }^{17}$

The key contribution of this research is that it challenges the idea that trade unions represent the labour aristocracy. Moreover, building on the recent developments stressed in our historical outlook, the analysis sheds light on possible tensions between the strategy of trade unions and their members' and supporters' expectations. While this research is limited to three companies and is unable to anticipate further developments, it adds to reflections on issues of global interest in the present period: the growing precarisation of workers, their relationship with trade unions, and the internal divisions among workers.

\section{Social conflicts and Slovenian trade unions: A historical overview}

11 The secession of Slovenia from Yugoslavia in 1991 and the restoration of capitalism also required the restructuring of trade unionism. While earlier sociological interpretations pointed out the exceptionality of Slovenia's resilience against neoliberal trends through social dialogue ${ }^{18}$ recent ones draw attention to its weaknesses. ${ }^{19}$ Combining these interpretations with ours, we outline three phases of trade union responses to changes in the labour/capital relationship since the end of socialism: 1 . The tripartite "social partnership" consolidated in the 1994-2004 phase that coincides with a decade of rule by the centre-left Liberal Party after the defeat of Slovenia's first (right-wing) government and social mobilisations triggered by a "reformed" former official trade union; 2. "Working-class" trade union militancy from 2005-2012 during a time of more intensive labour/capital polarisation, crises and social upsurges; and 3. Trends towards "economic unionism" or the "retreat" from representing the working class since 2013. This section starts by offering some general remarks about trade unions in the socialist past and then describes the outlined chronology while drawing upon the mentioned and certain other studies. ${ }^{20}$ 


\section{Trade unions, strikes and the Yugoslav self-management system} where a communist leading (single) party and the workers' state were supposed to "represent" the interests of workers. The role of trade unions was not better defined on the "Yugoslav road to socialism" following the 1948 break with the statist "Soviet model", characterised by the introduction of workers' councils from 1950 and by an extension of self-management rights. ${ }^{21}$ In the self-management system, strikes (although not legal, were recognised increasingly as legitimate) expressed the poor functioning of the system: they were an instrument of last resort for workers to use to defend their interests. Nada G. Novaković compiled research findings of the leading Yugoslav sociologists Neca Jovanov, Josip Županov, Nebojša Popov, Lidija Mohar, Vladimir Arzenšek and many others from the 1960s to the 1980 . $^{22}$ The study sheds light on two time periods: up until 1980, there were many fewer strikes than during the 1980s; they involved fewer workers and were much shorter (most not exceeding 1 day); and often achieved their goals, unlike what happened in the 1980s. As expressed in the title of Novaković's book, the change after 1980 reflects the sharp decline in workers' strength in the last decade of the system's open political and socio-economic crisis. Having failed to resolve problems within the workers' councils and the trade unions, workers were forced to rely on wildcat strikes. Trade unions kept their distance from these strikes, which were usually led by ad hoc strike groups. In contrast, trade unions behaved like "firemen"; they became engaged in strikes to end them quickly and peacefully. ${ }^{23}$ The trade unions only sporadically aligned themselves with the strikers.

Yet, as the study stresses, while their role in workers' strikes was ambiguous, the unions held a significant social function as a provider of foods, holidays and social activities for workers. They also managed the allocation of apartments owned by companies. Moreover, although industrial workers could not really enforce the selfmanagement rights assigned to them, they were able to benefit from the complementary efficient social management of public goods (health, education, pension, social care, etc.), which provided them with a high "social income". As Rastko Močnik stresses, "the social management in public services developed a successful pattern of democratic regulation of non-commodified production and social reproduction." 24

Another ambiguity of the system stemmed from the status of managers. Because they were considered wage workers, managers were also members of trade unions and even prevailed over industrial productive workers and administrative employees as the more active members of trade unions during socialism. The sociologist Arzenšek showed that the influence of management was seen in all fields, including investments, the pace of work, working time, and wage distribution. ${ }^{25}$ Still, workers had the right to choose and dismiss them, which was no longer the case after the immediate postsocialist period.

Since the break with the socialist system, the main form of democratisation has been through political pluralism - for political parties and trade unions alike. Voluntary membership, demands for the right to strike, and collective bargaining triggered a reform of Slovenian trade unions. Supporting the mine strikers in Kosovo and Istria at the end of the 1980s, trade unions in Slovenia demanded that the Association of Trade 
Unions of Yugoslavia recognise the rights to strike and collective bargaining and, later on, promoted these rights when they were involved in discussing amendments to the Slovenian constitution in the late 1980 s. $^{26}$

\section{Mobilisation of workers, trade union renewal and the social partnership}

The post-socialist trade union pluralism led to the founding of a new "conservative" Confederation of Independent Trade Unions of Slovenia (KNSS) as well as the "reform" of an official trade union (i.e. Association of Trade Unions), renaming it the Association of Free Trade Unions of Slovenia (ZSSS). The latter, although initially considerably weakened by the departure of some members who set up new trade unions, ${ }^{27}$ managed to keep a leading role in the renewal of the workers' movement.

Wages and privatisation were fundamental points of conflict facing the first conservative government of DEMOS (Democratic Opposition of Slovenia) after the country's independence in 1991. ZSSS resisted the plan for any rapid and generalised privatisation. In September 1991, while Prime Minister Jože Peterle was presenting the country's privatisation plan that drew on the proposals of Jeffrey Sachs (an American economist who played the role of adviser after having done so in Latin America), 10,000 workers marched in protest beneath his window. Later, a new law on privatisation was presented and ratified on the basis of a compromise drafted by the Slovenian economist Jože Mencinger ${ }^{28}$ that envisioned a more gradual form of privatisation (than Sachs' recommendations). In March 1992, ZSSS organised a general strike on another issue, this time against a draft law on wage restraint by which the government wanted to keep inflation under control. The trade unions called for higher wages, collective bargaining, and job protection. ${ }^{29}$ Although the two other confederations, KNSS and PERGAM, boycotted the strike, it involved up to 400,000 workers (for a total Slovenian population of about 2 million inhabitants) and the government was forced to withdraw the draft law. ${ }^{30}$

18 All of these actions led to the fall of the country's first right-wing government in $1992 .{ }^{31}$ According to Miroslav Stanojević, the power held by the trade unions resulted in a strong "social partnership," meaning that the labour force was genuinely involved in elaborating systemic laws and was firmly committed to maintaining the welfare state. ${ }^{32}$ This was analysed as a "neocorporatist" structure which Guglielmo Meardi dubbed the "Slovenian social model." ${ }^{33}$ After the defeat of more right-wing projects, a tripartite consultative body called the Economic and Social Council was established in 1994, which embodied the "Slovenian social model" until 2004. It included representatives of the government, employers' organisations, and trade unions, and had a right to discuss and give an opinion on draft legislation. In practice, no draft law in the areas of social, economic and especially labour policy could enter the parliamentary procedure without having first been discussed in the council. Trade unions accepted the council's role as a "social partner" with a view to establishing a "social market economy". The trade unions' strong social impact was reflected in a high trade union density rate (i.e. the ratio of trade union members to the total number of wage earners in the economy). This rate was between 60 and 70 per cent until 1994 and later stabilised at around 40 per cent until 2004. 

(EU). This goal was accomplished for Slovenia, along with eight other Eastern European countries in 2004. In 2007, Slovenia also entered the European Monetary Union (EMU). The trade unions thus became less resilient to the pressure of European negotiators who were asking for wage growth restraint and greater intensification of work: moreover, they did not open up the question of wealth redistribution. ${ }^{34}$ Meanwhile, the dominant party developed a way of privatisation that involved corruption and clientelism, which was denounced by the right-wing parties (before they themselves adopted similar practices upon coming to power). This led to the fall of the Liberal Party in 2004, the year Slovenia joined the EU.

\section{4-2013: The emergence of working-class unionism and the seeds of "retreat"}

The new right-wing government led by Janez Janša (elected in 2004) introduced neoliberal reforms in 2005. This generated a massive protest led by the trade unions. ${ }^{35}$ For almost a decade, trade unions displayed a new radicalism and, simultaneously, signs of indulgence that gave rise to the contradictory logics of concession-making.

Due to the huge mobilisation in 2005, the government was forced to withdraw its proposed flat-rate (and drastically reduced) tax, which was supposed to attract foreign capital. Almost simultaneously, ZSSS hired young activists who opened up the trade union agenda to include the rights of non-members, migrants and precarious workers. These efforts met with a great response among the population. Despite the 2009 recession, trade unions were able to win a 23 per cent minimum wage rise. In 2011, they organised a massive popular mobilisation against the neoliberal pension and labour reforms. Using the right to organise a popular referendum, they were able to defeat both draft laws. Globally, by fighting against these neoliberal reforms and defending the rights of the entire working population, including non-members and precarious persons, trade unions adopted a more offensive class confrontation and re-founded themselves on "class-based unionism."

In the meantime, other processes had already introduced the seeds of defeat into the above strategies. ${ }^{36}$ After the big victory over the government in 2005 , the trade unions agreed to return to negotiations: in fact, they exchanged the withdrawal of one reform (the flat-rate tax) for the government's promise to "limit inflation". For workers, this meant more work for the same or lower wages. On top of this, the unions did not question the new wave of privatisations already underway. The situation became worse. In 2006, employers were able to bring about the cancellation of the general collective agreement with the private sector, and the government made membership in the Chamber of Commerce and Industry no longer compulsory, against the chamber's will. As a result, the coverage of collective bargaining shrank rapidly to reach 65 per cent in 2013 (ICTWS database). ${ }^{37}$

Between 2006 and 2011, the union density rate oscillated around 30 per cent, but in 2012 it dropped to about 20 per cent..$^{38}$ Together with the general de-unionisation process, the tendency towards trade unions becoming more fragmented was reinforced. As noted, besides the transformation of ZSSS, four trade union confederations were established immediately after the secession from Yugoslavia, with their number later rising to seven confederations. To illustrate the level of 
fragmentation, we can take the example of the public sector where negotiations with the government even today still involve about 40 representative trade unions. Such fragmentation enabled the government to play the unions against each other, ${ }^{39}$ thereby considerably weakening their power.

The phase of growing polarisations came in the context of the international banking and financial crisis of 2008, followed by the "debt crisis" in the EU after the bailing out of banks and public interventions to slow the recession. This led to radical austerity politics under the pressure of European and international financial institutions and a new wave of social unrest..$^{40}$ The Slovenian "winter of discontent" in late 2012 and early 2013 was a grass-roots uprising against austerity measures. It started in November 2012, with people being determined to continue their protests until the government resigned. Under attack, the president of the right-wing government, Janez Janša, was responsible for the spread of rumours in the international press about the disastrous economic forecast for Slovenia, said to be on the edge of bankruptcy. Media reports triggered a rise in the interest rate for public loans, provoking a real financial crisis. ${ }^{41}$ Popular uprisings resulted in a vote of no confidence against the right-wing government and its fall, yet the crisis was not over.

\section{Since 2013: Towards "economic unionism"}

The new (centrist) government found itself in the grip of both the European Commission and the European Central Bank that were waving the spectre of the country's bankruptcy after the model of Greece, Portugal, Spain, Ireland and Cyprus. ${ }^{42}$ European institutions imposed unprecedented and harsh conditions on the recapitalisation of Slovenian banks, ${ }^{43}$ demanded that state-owned companies be privatised, and sought to weaken the trade unions since they stood in the way of the reforms. Trade unions were seriously affected in May 2013 when the parliament, under the threat of an EU bailout, amended the Constitution to forbid the right to organise popular referendums on all issues concerning fiscal matters, defence and international regulations. ${ }^{44}$ This prohibition on referendums on these issues took away a powerful tool from the trade unions for combatting anti-labour proposals. The labour reform in 2013 was probably the last ambitious project of the social partners with which the trade unions tried to restrain precarisation. Though ambitious, the overall long-term effects of this reform have brought only disappointing results. Since 2014, the economic recovery has relied significantly on the employment of precarious workers.

Since 2013, trade unions have not been able to regain their past anti-systemic power. However, a change in trade union strategy was explicitly formulated only in 2017 in the inaugural speech of Lidija Jerkič, the newly elected president of the largest trade union ZSSS. She introduced the slogan "back to the membership," 45 by which she appealed for a switch from class-based unionism to "economic unionism." Under the new strategy, trade unions tend to serve the immediate interests of their members rather than the general interests of all workers, including migrant and precarious workers. Moreover, the high level of trade union fragmentation triggered strong competition among them and a ruthless struggle for better deals, usually to the detriment of other unions. The uneven wage increases obtained by trade unions in the public sector in December 2018 show the lack of solidarity among workers. Namely, the campaign for higher wages 
initially revolved around workers with the lowest wages, thereby attracting sympathies, yet ultimately this group of workers received the smallest wage increases.

This dual trend of worker stratification and a change in trade union strategy lies at the core of the case study which we analyse below.

\section{Greater stratification of workers} firm into a multinational with subsidiaries in nine South-East European countries. At the time of the research, it had around 400 employees; the whole group about 1,000. More than half the employees are members of two trade unions. In 2006, a financial holding (owned by the Catholic Church) became the majority owner, but it went bankrupt in 2010 due to being unable to pay the debts it incurred for leveraged buyouts. In this situation, both the management and the employees took steps to cut costs with a view to rescuing the enterprise. The company also sold off most of its foreign subsidiaries. During the crisis, the key partner of the management was the trade union. To date, the company is still unsold. extreme stage with record levels of bankruptcy and unemployment. In interviews, we could feel the pressure on both management and workers who were struggling to keep their factories alive and sought to cope with the anticipated restructuring, downsizing, 
relocation and privatisation of companies. Among the three sectors, printing and publishing were particularly affected by financial speculation in this period. The Catholic Church took over the publishing company in our study through a leveraged buyout and, unable to repay its debts once the crisis erupted, put the company on sale for a price below its liquidation value, exposing the employees to yet another speculative acquisition. ${ }^{46}$ The printing industry also suffered numerous takeovers, mergers and buyouts that often led to the downsizing and bankruptcy of the companies acquired. An established printing enterprise with 300 workers went bankrupt in 2009, 4 years after it had been taken over. The owner pocketed all of the company's cash reserves by issuing false invoices and depositing the proceeds in tax havens. ${ }^{47}$ Several months of wages and the severance pay of dismissed workers went unpaid.

These two examples illustrate the destructive force of credit-driven economic growth. They help to understand the uncertainty of workers when they are confronted by the bearers of small and medium-sized capital. Such capital "carried out the 'dirty work' of destroying the [...] traditional relations of production and in the process either founder[ed] in ruins or prepare[d] the ground for the 'normal' production of surplus value." 48 These general observations were reflected in the survey conducted in the paper, printing and publishing companies with respect to how workers felt about their job security and working conditions.

the survey, workers were asked to select the most adverse factors in their workplace. They were asked to rate eight indicators on a scale from 1 to 5: "fear of losing employment," "poor salary," "hard work," "excessive working hours," "mobbing," "risk of occupational diseases and injuries," "monotonous work" and "changes and reorganisations." Two factors - "low pay" and "fear of losing employment" - by far received the highest scores as the factors most troubling for all employees.

In the publishing company, the workers' anxiety could be explained by the fact that a prospective buyer was conducting due diligence during the time of the research. As for the paper company, it was under the threat of the government's decision to sell off state-owned companies. This was less evident in the printing company, which is a subsidiary of a multinational corporation where workers also scored "fear of losing employment" as a high risk, even though this company's performance was very good. Our conversations with the trade union representatives and the manager helped us to understand that these fears all referred to the possibility of relocating the plant to another country (with lower taxes and lower labour costs). The parent company was using the idea of restructuring and relocating the plant as a means to exert constant pressure on its workers.

However, while all workers had to intensify their work and all wages were lowered or stagnating, the effects were not equal across all worker groups. Our findings show that the measures adopted in response to the crisis clearly affected the production workers more harshly than they affected supervisors and management.

First, workers did not all have the same risk of losing their jobs. Redundancies in companies that urgently needed to cut their costs during the crisis were disproportionately high among low-skilled workers. In the paper company, 33 per cent of workers who had completed primary education or less were made redundant in the period 2008-2013, while only 11 per cent of workers with a vocational education, 16 per cent with a high school degree, and 6 per cent with a university degree were laid off. In the publishing company, 26 per cent of employees with a lower education, including 
high school graduates (the average education level in this company was higher), lost their jobs but only 11 per cent of employees with a higher education lost their jobs. Therefore, high-skilled employees had greater job security than low-skilled workers.

Second, the low-skilled workers reported working conditions that were more difficult. We confirmed the correlations between "low education level" and "hard work," "excessive working hours," "monotonous work," "risk of occupational diseases and injuries," "changes and re-organisations" in the paper company, ${ }^{49}$ and the correlations with "risk of occupational diseases and injuries," "changes and re-organisations," "low wage" and "hard work" in the publishing company. ${ }^{50}$ The intensification of work apparently affects low-skilled workers more than their better-educated co-workers.

Third, all employees almost unanimously rated "low pay" as the most disturbing factor. Wages set at around the minimum wage facilitated methods for the extracting of surplus value, which the management widely relied on during the crisis. While analysing the data, we discovered the contradiction that the workers in the printing company, where the average wage was 27 per cent above the average for the industry, were as discontent with their wages as the workers in the paper company where the average wage was 13 per cent below the industry average. Moreover, both were even more dissatisfied than those working in the publishing company where the average wage was 14 per cent below the industry average.

During the interviews with trade unionists in the printing company, we found that the management regularly makes small wage increases conditional on the further intensification of labour. ${ }^{51}$ In the past, workers could work overtime on weekends and some, eager to earn extra money, had been accumulating record overtime hours until the Labour Inspectorate made a check of the company and banned the practice. There are other similar practices. Production workers receive a bonus of 0.75 per cent of pay per hour for each day if the "machines run without interruption." ${ }^{2}$ Instead of scheduled breaks, workers take rest breaks during the working day only if and when they can afford to, for which they receive about 10 per cent of their wage as a bonus. Further, although two printers usually work with one machine, the company offers a bonus of 50 per cent of basic salary per hour if the work is done by one person. And, the company offers on-job training to unskilled workers to take on work that is typically carried out by qualified printers. This is a kind of special reward for loyal and hardworking persons, but after the completion of training, the company pays the worker more than before, but less than it would pay a skilled worker. Workers know that all of these bonuses are only temporary until they become accustomed to intensified work, but are still forced to exchange more intensive work for the necessary (or desired) level of income. ${ }^{53}$ As we can see, "extra" payment above the industry average consists of bonuses and, for this reason, workers may feel deprived of reasonable pay.

As in the printing factory, the paper company has also resorted to various methods for intensifying work. The company had been in the red some years before our research and had been pushing its workers to work harder with the fear of bankruptcy and unemployment rather than with monetary incentives. Between 2009 and 2012, it reduced the number of employees by 15 per cent and, although no significant technological investments were made, the company succeeded to produce the same output as before. Consequently, those who remain have had to take over the tasks of the missing workers, as one trade union representative described, "After the departure of workers, instead of eight, now only five work per shift [i.e. on one production line] 
and three workers were not replaced, but their work was reallocated to the others, meaning that each received additional tasks. ${ }^{54}$ This practically means that while before one worker worked with one machine, now one must work with two - and has to work at high speed for all eight hours. In the final weeks of our research, the paper company adopted the same policy as the printing factory that the machines must never stop, not even for a break. Workers retained the right to a half-hour break during the eight-hour working day as the labour law requires, but they must ensure that the machines work constantly and take a break in the waiting time or when a replacement worker is available. As workers explained in the focus group, the only possible solution, if the machines are to operate continually, is the workers' voluntary shortening of their rest breaks. ${ }^{55}$ In this way, the management is eroding the legal right of workers to a half-hour break: while workers still have the right de jure, they cannot exercise it de facto. ${ }^{56}$

The working conditions are generally better in the publishing company, but even here we find departments under extreme pressure with respect to the pace of work. Workers in the call centres receive a minimum wage if they reach a set work norm. For any work beyond that, they receive "nice" financial incentives. ${ }^{57}$ However, when most workers manage to achieve the work norm, the company unilaterally raises it, so the workers end up again toiling for the minimum wage.

Examples from all three companies show that the workers enjoy different levels of employment, work and income security ${ }^{58}$ Everywhere we find a tier of workers whose poor working conditions and low income place them in a very tough situation. Wages set at around the minimum wage ${ }^{59}$ do not provide for all of their basic needs, so they must earn more and desperately want to do so. For this reason, they are easy targets of demands for more work in exchange for small payments. ${ }^{60}$ As they earn wages that place them at risk of poverty, they are subjected to "factory despotism," (i.e. to the permanent exchange of more work for small extra payments) much more than other workers. The logic runs as follows: the additional efforts made by workers for extra payments will over time become the standard work norm, covered by the standard wage, and the worker will then have to work even harder to gain any additional pay. Consequently, the system drives them to exploitation beyond their biological capabilities, past the natural exhaustion of their bodies. From a legal point of view, their employment is secure (fixed-term). The "security" of their employment certainly makes a difference but, as workers often stated in the interviews, the legal protection of their job does not count for much in a very unsteady economy. In many other respects, such as income insecurity and health hazards, they are precarious. As an International Labour Organisation (ILO) report stresses, "precarity can be found also within standard employments, if, for example, the wages are at the poverty level, if the continuity of their job is uncertain, or if the job exposes the worker to occupational hazards." 61

\section{Political differentiation in the workplace}

In the previous section, we established that workers are not equally affected by the risk of losing their jobs, the intensification of labour or wage restrictions. The differing situations indicate what we have labelled the "technical composition of the labour force" involves stratification; there is a very uneven evolution in working conditions 
and those at the bottom suffer the greatest deterioration. We now turn to the "political composition" of the labour force in relation to its stratification, as defined in the introduction, by combining two approaches: the study first presents the demographic characteristics of trade union members and then workers' expectations of trade unions in the three companies.

\section{Demographic characteristics of trade union members}

In the paper company, 91 per cent of the workers are trade union members, in the publishing company 63 per cent are members, while in the printing company 49 per cent of all workers are divided between two trade unions.

For the paper company, statistical tests confirmed correlations between "age," "gender," "education" and "trade union membership." Older workers are more likely to be trade union members than younger ones; there is a bigger share of women than men in the trade union (95 per cent of women compared to 87 per cent of men); ${ }^{62}$ and less educated workers are more likely to be trade union members than more educated ones. ${ }^{63}$ More specifically about the latter: 69 per cent of those who hold a university degree are unionised compared to 92 per cent of those who have completed secondary or vocational school and to 98 per cent of those who have complete or partial primary school education.

The survey of the publishing company shows similar results: higher proportions of older workers as well as female workers are likely to become trade union members. ${ }^{64}$ There is also a strong positive correlation between trade union membership and the low educational background of employees: while only 48 per cent of those who have a university degree are union members, 82 per cent of those with a lower level of education are members of the trade union. ${ }^{65}$

The sample in the printing company was much smaller, allowing us to confirm only the correlation with the variable "education," ${ }^{66}$ evident in all three cases. As workers with lower education are usually paid less, this implies that lower-paid employees prevail among trade union members in all three companies.

This confirms the finding, so far revealed only in public opinion polls, ${ }^{67}$ about the actual dominance of workers with a lower income level among trade union members. More importantly, our findings speak against the critical view that trade unions are organisations of the "labour aristocracy." While debates over labour aristocracies and the labouring poor are still significant in Slovenia (as elsewhere), our study raises some doubt that Slovenian trade union membership consists of the "labour aristocracy". The three cases we considered rather connect trade union membership with the labouring poor. Of course, it is important to note that the study only covers limited examples and does not include examples from the public sector. However, it proves that we must be careful about any references to a "labour aristocracy." We should not confuse two analytical levels: the analysis of trade union membership (as analysed here) and the political strategies of trade union leaders (as stressed in the first part). 


\section{Workers' views on trade union activities}

51 After presenting the demographic characteristics of trade union members, we examine workers' views on trade unions. Both approaches together are expected to yield information about the "political composition of the labour force."

For this purpose, we asked respondents to rate their preferences about proposed trade union activities on a 5-point scale. Taken together, all respondents held preferences for five trade union activities - "to represent workers before the government and employers" (average score of 4.5), "wage increases" (4.43), "legal assistance" (4.4), "improvement of working conditions" (4.36), "solidarity aid" (4.26) - over apparently four less important activities, namely "leisure activities (sports, outings, gatherings)" (3.3), "education" (3.23), "holiday facilities" (3.133) and "food bank" (2.6). It is clear that the respondents classified two groups of activities in two different groups of major and minor importance. In order to identify the main dimensions of what respondents believe the labour union should be performing, principal component analysis (PCA) was conducted on a set of variables measuring union activities. The PCA method reduces the dimensions of the data by extracting the main components in the variables which explain the greatest amount of the data dispersion. Based on the components gained, different clusters of respondents were identified. Two analyses of this type were conducted, namely in the paper and publishing company, since the sample in the printing company was too small.

The conducted PCA method of the respondents' preferences for trade union activities split the publishing company's workers into two groups. The larger group (80 per cent of respondents answering this question) varied from the smaller one (20 per cent of respondents) with stronger support for trade union activities. As expected, a statistical test confirmed that trade union members are more supportive than non-members. What is more interesting is that the bulk of non-members classified themselves as "supporters": 67 per cent of non-members supported the trade unions' activities.

The clustering of answers with the same method in the paper company based on the same block of questions split the respondents into three groups. The smallest group (5 per cent of respondents answering this set of questions) is categorically opposed to all trade union activities ("non-supporters"), while the second group (47 per cent of respondents) supports all trade union activities ("supporters") and the third group (48 per cent of respondents) only supports some activities ("restrained supporters"). Once again, the group of "non-supporters" is the smallest, while non-members (less than 10 per cent of workers) support the trade unions. It is worth stressing that more educated and better-paid workers generally tend to support unions, but are less willing to become members. The literature usually presents the issue of silent supporters who are able to benefit from some trade union achievements without paying the price (i.e. the membership fee) as the "free rider" problem. ${ }^{68}$ However, this explanation is highly improbable in our case regarding why only better-paid workers would prefer to rely on a "free ride," while their poorer counterparts are willing to pay. We now try to shed light on the reasons that the upper tiers of company hierarchies usually abstain from trade union membership by analysing their attitudes to various trade union activities.

We thus draw attention to the difference between the "supporters" and "restrained supporters" groups. While the "supporters" did not distinguish the trade union activities very much, the "restrained supporters" appreciated five activities but were 
extremely reluctant towards others, such as "holiday facilities," "food bank" and "leisure activities." ${ }^{69}$ In contrast to the "restrained supporters," the "supporters" appreciate some commodities or services which the trade union offers at a lower price and which they might possibly not be able to afford (holidays, food). They also attach importance to trade union sports activities, gatherings and events. For the want of things from food to leisure, they need trade union support mechanisms in order to survive as well as to socialise. Therefore, in a way this makes this group supportive of the maintenance of a "working class culture" as well as the sharing of goods and beliefs.

In the publishing company, the PCA analysis showed only two groups, "supporters" and "non-supporters." Nevertheless, the analysis confirmed the statistical significance between "low education" and "food bank" as well as between "low education" and "holiday facilities." ${ }^{70}$ This means that workers with a low education level (and therefore lower incomes) hold a greater affinity for the food bank and holiday facilities than higher-educated workers.

Their expectations contradict the current trade unions' policy of making a break from the "socialist past." Trade union officers often link these activities ("holiday facilities," "food bank," "leisure activities") to the socialist past from which they have been trying to distance themselves ever since the trade union reforms in the 1990s. For them the expression "food bank" (ozimnica in Slovenian) symbolises all that should not inspire contemporary trade unionism. It represents the "backwardness" of the socialist trade unions and differs from a "real modern way" of doing trade unionism; namely, social dialogue, negotiations, representation and legal advocacy (all of which express integration into a capitalist social relationship). The trade union officers' own mind-set thus gravitates more towards that of the "restrained supporters" (who prefer the more distant role of the trade union as a negotiator, representative or lawyer, particularly in the most recent phase of "economic unionism") than "supporters" (who also appreciate the integrative role of trade unions as a bearer of working-class culture). The research lays bare the contradiction that while the core basis of trade unions consists of "supporters," actual trade union strategy (including economic unionism) gravitates more to the preferred positions of "restrained supporters." While comparing our case study and the evolution of trade union strategies, we can say that by distancing themselves from the "supporters," the trade unions are also loosening the ties with their core membership.

Leaving aside the tiny group of "non-supporters" in the paper factory, both analyses isolated two different groups holding dissimilar views on trade unions. While all workers generally support trade unions in the publishing and the paper companies, those with a lower education and lower wages also tend to associate trade unions with a distinctive "class culture" concerning access to services and fundamental goods (therefore rights and "dignity"). The second group, consisting of workers who are paid better and have higher education levels, is less likely to support this "class-based culture" or to become trade union members. This group does not abstain from membership only to get a "free ride." The second group may support trade unions because any improvements attained in the collective negotiations are to their benefit too. However, improvements in wages and working conditions for workers found at the bottom of hierarchy might not be in their interest. Such improvements would, in the present system, make the company less "competitive" and lead to job losses and lower 
income security for all workers. A free ride is hence a wrong way to view the problem. The second group depends existentially on a growing exploitation of the lower tiers of production and service workers. Thus it is not the cost of the ride but the incompatibility of interests that keeps this group out of trade union membership.

The incompatibility of perceptions indicates specific workplace struggles. The word "struggle" here refers to the conflict involving "social representations" that should, according to Durkheim, be treated as social facts. More importantly, the word "struggle" refers to the basic contradiction between the capitalist and working classes, established in the very act of subordinating workers to capital and appropriating the surplus value they produce. This is the very moment when the class struggle comes into play, while industrial conflicts are consequences of this fundamental contradiction (the passage from a class-in-itself to a class-for-itself). What we add to the notion of struggle is that we must observe "workplace struggles" in their dual complexity as struggles between labour and capital as well as struggles within the working class (among various worker groups).

The research also shows that this complexity of workplace struggles demands a theoretical re-thinking of the current system of "co-exploitation" whereby workers at the bottom of the hierarchy are co-exploited by their waged "superiors" and higher levels of "capitalist" management. On the practical trade union level, this theoretical reflection is needed to properly address the problem of poverty and precarity among workers.

\section{Conclusion}

In the first section, we established that while labour/capital antagonism has deepened, trade unions have lost their strength through a long process of fragmentation. This historical overview shows that trade unions have turned their back on representing the working class. After 2004, they were confronted with harsher external pressures from European and global capital institutions. Defeated, they started to compete with each other in order to obtain better deals for their members. The propensity to defend the "general interests of the working class" - inherited from the country's socialist past and based on mass mobilisation which helped develop the Slovenian model of industrial relations in the early 1990s - has gradually disappeared from trade unions' practices. The strategies of trade unions are converging increasingly with the interests of groups that possess considerable bargaining power.

Historical analysis that looks at the re-positioning of trade unions within labour/ capital relations might have us believe that trade unions mostly represent upper-layer workers (i.e. the "labour aristocracy"). Yet, our case study produces quite a different picture. The analysis of trade union membership in three companies showed that workers with a lower education and lower wages were more likely to be trade union members than were their more educated and better-paid colleagues. Indeed, the analysis revealed that workers who possess the worst working conditions overlap with trade union membership. We also underlined that their working situations are akin to today's particularly questioned status of a precarious worker. Therefore, contrary to the general conviction that trade unions represent better-off employees with guaranteed employment, we found that the membership structure analysed in our case study reflected both working poverty and rising precarity. 
63 Moreover, the analysis also showed that the trade union strategies were not transformed to reflect a change in their membership structure, but to loosen their ties with their core membership and social basis. We argue that this radicalisation of the labour/capital contradiction corresponds with discordances in the trade union/ membership relationship, and that the deadlock in dialogue between labour and capital is leading to growing tensions in the workplace. However, we can also see the connection between the two relationships (labour/capital relations on one side and the trade union/membership relations on the other) the other way around. By pursuing the immediate interests of better-off trade union members, trade unionism is simply reflecting the increasing fragmentation of the workforce. Ironically speaking, these two relations have established some kind of "new balance," with the fragmentation of trade unions reinforcing the rising inequalities among workers.

Our research showed that the efforts of management and the trade unions to keep the companies afloat during the crisis and to save jobs had different impacts on various worker groups. The intensification of labour and wage restrictions placed a heavier burden on low-paid manual workers (direct producers) than on other strata of workers. This situation generates the contradictory process where all employees benefit from the greater exploitation of certain production and service workers. This contradiction, in turn, raises debates about the "co-exploiting" of workers and calls for further scientific research about the divisions among wage workers mentioned in the introduction.

With regard to future research, we stress that our research does not support the view that the growing inequalities seen among workers are the result of a bipolar model with management or bureaucracy on one side and workers on the other. From an organisational point of view, the three companies we analysed possess a simple vertical structure. If we had conducted a similar analysis in companies with more complex modular or supply chain production, we would likely have discovered a chain structure in which all worker groups could receive some incentives to exploit others (while being themselves exploited at the same time), except for those found at the bottom of the hierarchy.

\section{NOTES}

1. BoHLE Dorothee, Greskovits Béla, Capitalist Diversity on Europe's Periphery, Ithaca and London, Cornell University Press, 2012.

2. Ibid., p. 213.

3. BacCaro Lucio, Howell Chris, "A Common Neoliberal Trajectory: The Transformation of Industrial Relations in Advanced Capitalism," Politics \& Society, vol. 39, $\mathrm{n}^{\circ}$ 4, 2011, p. 521-563.

4. T ERRAY Emmanuel, "Prolétaire, salarié, travailleur productif," Contradictions, $\mathrm{n}^{\circ} 2$, JulyDecember 1972. Quoted in BAUDELOT Christian, ESTABLET Roger, M ALEMORT Jacques, La petite bourgeoisie en France, Paris, François Maspero, 1981, p. 17. 
5. HовSваWм Eric, Labouring Men: Studies in the History of Labour, London, Weidenfeld Goldbacks, 1964. НовSвАWм Eric, Worlds of Labour: Further Studies in Labour History, London, Weidenfeld and Nicolson, 1984.

6. Ibid.

7. PoulantZAS Nicos, Classes in Contemporary Capitalism, London, NLB, 1975. Yet, for him, some productive workers also form a segment of the petty bourgeoisie, for instance, engineers and technicians who participate in production but also "maintain political and ideological relations of subordination of the working class to capital (p. 242)."

8. BAUdelot Christian, EstABlet Roger, MALEMoRT Jacques, La petite bourgeoisie en France, op. cit.

9. DuméNIL Gérard, LÉvy Dominique, Managerial Capitalism: Ownership, Management and the Coming New Mode of Production, London, Pluto Press, 2018.

10. Cf. BAUdelot Christian, ESTABLET Roger, MALEMORT Jacques, La petite bourgeoisie en France, op. cit. 11. For an explanation of the two concepts, see NEGRI Antonio, Dall'operaio massa all'operaio sociale, Ombre corte, Verona, 2007 [1979], for further elaboration, see MočNIK Rastko, "Trg delovne sile in sestava delavskega razreda" [The Labour Market and Composition of the Working Class], Teorija in praksa, vol. 48, $\mathrm{n}^{\circ} 1,2011$, p. 178-205. Maria Turchetto gives the following definition: “'Class composition' was intended to express the bond between the objective technical characteristics evinced by labour-power at a given historical moment, as a result of its position within the capitalist organisation of the production process, and its subjective, political characteristics ( $p$. 288)." TURCHETTO Maria “From 'Mass Worker' to 'Empire': The Disconcerting Trajectory of Italian Operaismo," in Jacques Bidet, Stathis Kouvelakis (eds.), Critical Companion to Contemporary Marxism, Leiden-Boston, Brill, 2008, p. 285-308.

12. Italian Operaisti considered the unskilled ("mass") workers as the bearers of revolutionary subjectivity, resisting the compromised labour organisations (the so-called yellow unions) as well as factory despotism.

13. The anonymisation of companies in the research outputs was requested by the management as a precondition for conducting the research due to concerns over the impact of potentially unfavourable research outcomes on the company leadership. A concern with negative publicity was present among the trade union leadership while the leaders also feared that public disclosure of the research results on the (low) wages received by trade union members would deter workers who wished to earn higher wages from becoming members of the trade union. Therefore, the researchers had to agree to not disclose certain data.

14. The company was privatised in 2016.

15. These documents were found in the companies' annual reports submitted to AJPES (Agency of the Republic of Slovenia for Public Legal Records and Related Services), articles in the journals of professional associations (e.g. Papir, Grafičar, Knjižnica), reports of international organisations within the branch (CEPI, Intergraf, Federation of European Publishers) and statistical data provided by AJPES, SURS (Republic of Slovenia Statistical Office) and Eurostat.

16. The average length of an interview was 65 minutes.

17. The average length of a focus group was 121 minutes.

18. Bohle Dorothee, GresKovits Béla, Capitalist Diversity on Europe's Periphery, op. cit.; CROWLEY Stephen, STANojević Miroslav, "Varieties of Capitalism, Power Resources, and Historical Legacies: Explaining the Slovenian Exception," Politics \& Society, vol. 39, n 2, 2011, p. 268-295; MEARDI Guglielmo, "More Voice after More Exit? Unstable Industrial Relations in Central Eastern Europe," Industrial Relations Journal, vol. 38, n 6, 2007, p. 503-523.

19. Stanojević Miroslav, "Slovenia: Neo-Corporatism under the Neo-Liberal Turn," Employee Relations, vol. 40, $\mathrm{n}^{\circ}$ 4, 2018, p. 709-724; K RAŠOvec Alenka, JoHANNSEN Lars, "Social Dialogue between Transition and the Great Recession," Teorija in praksa, vol. 54 (Special Issue), 2017, p. 
30-44; BEMBič Branko, "From Victory to Victory to the Final Retreat: Changing Balance of Class Forces in the Slovenian Transition," Tiempo Devorado, vol. 4, n² 2, 2017, p. 363-398.

20. STANojević Miroslav, "Sindikalne strategije v obdobju krize" [Trade Union Strategies at a Time of Crisis], Teorija in praksa, vol. 52, $\mathrm{n}^{\circ}$ 3, 2015, p. 394-416). The three trade union strategies are elaborated in: HyMAN Richard, Understanding European Trade Unionism, Between Market, Class \& Society, London, Sage, 2001.

21. SAMARY Catherine, Le marché contre l'autogestion: L'expérience Yougoslave, Paris, Publisud - La Brêche, 1988; SAMARY Catherine, Komunizem v gibanju [Communism in Motion], Ljubljana, Založba /*cf, 2017; KRŽAN Marko, "Jugoslovansko samoupravljanje in prihodnost socializma" [Yugoslav Self-Management and the Future of Socialism], in Catherine Samary, Komunizem v gibanju), op. cit., p. 213-242.

22. NovaKović Nada G., Propadanje radničke klase [Decline of the Working Class], Belgrade, Rad, 2007.

23. Ibid., p. 124.

24. Cf. MоČNIK Rastko, "Workers' Self-Management in Yugoslavia - Possible Lessons for the Present," in website of Ozren Džigurski, n.d., online: http://ozrendzigurski.com/index_files/ Page1305.htm (accessed in June 2020).

25. ARZENŠEK Vladimir, Strukture i pokreti [Structures and Movements], Belgrade, Centar za filozofiju i društvenu teoriju, 1984.

26. Vrhovec Pavle, Pernat LesjaK Staša, Sindikalno gibanje skozi čas [Trade Union Movement through Time], Ljubljana, in website of Association of Free Trade Unions of Slovenia, May 2015, online: http://sindeks.si/wp-content/uploads/2016/07/sindikalno_gibanje_skozi_cas.pdf (accessed in June 2020).

27. In the early 1990s, the following trade unions split from ZSSS: Confederation PERGAM in the paper and graphics sector, Confederation KS-90 in the Littoral region; Teachers' trade union SVIZ, Trade Union of Health and Social Care, and Trade Union of Railway Workers. See also, VRHOVEC Pavle, PERNAT LESJAK Staša, Sindikalno gibanje skozi čas, op. cit., p. 21.

28. The law was adopted in November 1992. Cf. MenCINGER Jože, "Privatization in Slovenia," in website of the Faculty of Law, University of Ljubljana, n.d., online: http://www.pf.uni-lj.si/ media/mencinger.privatization.pdf (accessed in June 2020).

29. "25 let od prve splošne stavke v Sloveniji” [25 Years since the First General Strike in Slovenia], in MMC RTVSLO, 15 March 2017, online: https://www.rtvslo.si/slovenija/25-let-odprve-splosne-stavke-v-sloveniji/417376 (accessed in June 2020).

30. GRDEŠIĆ Marko, “Tranzicija, sindikati i politike elite u Sloveniji i Hrvatskoj” [Transition, Trade Unions and Political Elites in Slovenia and Croatia], Politika misao, vol. 43, n 4, 2006, p. 121-141; GRDEŠÍ Marko, "Mapping the Paths of the Yugoslav Model: Labour Strength and Weakness in Slovenia, Croatia and Serbia," European Journal of Industrial Relations, vol. 14, n 2, 2008, p. 133-151. 31. A new left-centrist government was led by Janez Drnovšek, former chairman of the Collective Presidency of Yugoslavia in 1989-1990, then leader of the Liberal Democratic Party which was a legal successor of the Association of Socialist Youth of Slovenia.

32. Stanojević Miroslav, Broder Živa, "Trade Unions in Slovenia: Historical Development and the Current Situation," SEER: Journal for Labour and Social Affairs in Eastern Europe, vol. 15, n 3, 2012, p. 303-313.

33. MEARDI Guglielmo, "More Voice after More Exit? Unstable Industrial Relations in Central Eastern Europe," Industrial Relations Journal, vol. 38, nº 6, 2007, p. 503-523; CROUCHER Richard, RIzOV Marian, “Union Influence in Post-Socialist Europe," Industrial Labour Relations Review, vol. 65, n 3, 2012, p. 630-650; GLASSNER Vera, "Central and Eastern European Industrial Relations in the Crisis: National Divergence and Path-Dependent Change," Transfer, vol. 19, n 2, 2013, p. 155-169.

34. Stanojević Miroslav, "Sindikalne strategije v obdobju krize," op. cit., p. 407-408. 
35. "Fotozgodba: Protest sindikatov" [Photostory: The Trade Union Protest], MMC RTVSLO, 26 November 2005, online: https://www.rtvslo.si/slovenija/fotozgodba-protest-sindikatov/46542 (accessed in June 2020).

36. STANOJEvić Miroslav, "Sindikalne strategije v obdobju krize," op. cit., p. 409.

37. VISSER Jelle, "ICTWSS Database," Amsterdam Institute for Advanced Labour Studies (AIAS), University of Amsterdam, November 2019, online: https://www.ictwss.org/downloads (accessed in November 2020).

38. BRODER Živa, Sindikalno gibanje v Sloveniji od osamosvojitve do danes [Labour Unions in Slovenia from Independence till Today], Master's Thesis, Faculty of Social Sciences, University of Ljubljana, 2015, p. 41. The biggest trade union ZSSS, for instance, had 64 per cent of all trade union members in 1991, while by 2015 it had only 40 per cent.

39. Ibid., p. 42.

40. STANojević Miroslav, Kanjuo-MrČEla Aleksandra, BRezniK Maja, "Slovenia at the Crossroads: Increasing dependence on supranational institutions and the weakening of social dialogue," European Journal of Industrial Relations, vol. 22, n³ 3, 2016, p. 281-294.

41. DamiJAN Jože P., “Je mar Janez Janša neprišteven?" [Is Janez Janša insane?], Damijan Blog, 3 September 2012, online: https://damijan.org/2012/09/03/je-mar-janez-jansa-nepristeven/ (accessed in June 2020).

42. For a more detailed account of the crisis, see: SAMARY Catherine, "Quelle réelle crise en Slovénie?," in website of Committee for the Abolition of Illegitimate Debt, 2013, online: http:// www.cadtm.org/Quelle-reelle-crise-en-Slovenie (accessed in June 2020); B REZNIK Maja, F URLAN Sašo, “Kje je Slovenija v dolžniški krizi?” [Where is Slovenia in the Debt Crisis?], in Maja Breznik, Rastko Močnik (eds.), Javni dolg. Kdo komu dolguje? [Public Debt. Who Owes Whom?], Ljubljana, Založba /*cf, 2015; KRŽAN Marko, "Crisis in Slovenia: Roots, Effects, Prospects," METU Studies in Development, vol. 41, ñ 3, 2014, p. 323-348; P ODVRŠř Ana, "Evroobmočje in periferizacija slovenskega gospodarstva" [Eurozone and the Peripheralization of the Slovenian Economy], in Miroslav Stanojević, Sašo Furlan (eds.), (Ne)dostojno delo [(In)decent work], Ljubljana, FDV, 2018, p. 27-51.

43. In spring 2019, the criminal police concluded a long investigation into the recapitalisation of Slovenian banks in 2013. It charged the governor and vice-governors of the Bank of Slovenia with criminal acts. The investigation found that the European Commission's officials imposed on the Bank of Slovenia a methodology for calculating the bank deficit that was inconsistent with international accounting standards. Although international firms Oliver Wyman, Roland Berger, Deloitte, and Ernst \& Young officially signed off on the audit, the investigation revealed that European officials themselves decided about the (presumed) bank deficit. For this reason, the deficit was expanded from EUR 375 million, as established by the Slovenian audit in the first place, to EUR 4.7 billion. In response to the investigation, the European Commission filed a lawsuit against Slovenia with the charge of "breaking the secrecy of the European Central Bank's archive." The investigation report was presented by the journalist Borut Mekina in two articles: "Štirje tipi o milijardah" [Four Guys about Billions], Mladina, 3 May 2019; and "Kdaj bomo spregledali?" [When Will we Realise?], Mladina, 10 May 2019.

44. Constitutional Act Amending Articles 90, 97 and 99 of the Constitution of the Republic of Slovenia (UZ90, 97, 99), Official Gazette of the Republic of Slovenia, $n^{\circ} 47 / 13$ of 31 May 2013.

45. "Nova predsednica ZSSS-ja Lidija Jerkič: Čas je, da delavci zahtevajo več" [New President of ZSSS Lidija Jerkič: It Is Time for Workers to Demand More], MMC RTVSLO, 4 October 2017, online: https://www.rtvslo.si/slovenija/nova-predsednica-zsss-ja-lidija-jerkic-cas-je-da-delavcizahtevajo-vec/434247 (accessed in June 2020).

46. BREZNIK Maja, Za napisom Nezaposlenim vstop prepovedan [Behind the Notice No Admission Except for Business], Ljubljana, KSS Pergam, 2014, p. 30-31. 
47. FRIŠEK Božo, “Adijo, tovarna. To je le moja zgodba - ena od mnogih” [Goodbye, Factory. This Is just my Story - One of Many], Delo, 13 November 2013, online: https://www.delo.si/adijotovarna/adijo-tovarna-to-je-le-moja-zgodba-ena-od-mnogih.html (accessed in June 2020).

48. MANDEL Ernest, Late Capitalism, London, Verso, 1978, p. 48.

49. With statistical significances $.000, .004, .007, .008$ and .045 for the chi-square test, respectively.

50. With statistical significances $.000, .000, .000$ and .003 , respectively. Due to the small number of respondents, we could not conduct such tests in the printing company. However, descriptive statistics suggest similar conclusions for this case too.

51. Interviews with two trade union representatives (6 and 23 December 2013) as well as a manager (6 December 2013) from the printing company.

52. Data from an interview with a manager from the printing company (6 December 2013).

53. For similar findings, see: PhiLIP Bruce, WhEATLEY Dan, "European Work Time Regulation, Surplus-Value and Underemployment among Full-Time Employees: A Cross-Sectional Analysis using the 2009 EU LFS," Economic lssues, vol. 18, n 1, 2013, p. 57-74, p. 71.

54. Interview with a trade union representative from the paper company, 22 January 2014.

55. Data from the focus group with workers from the paper company, 24 June 2014.

56. Note that workers cannot renounce taking a break as "a worker who works full-time shall have the right to a 30-minute break during the working day" (Article 154, Employment Relationship Act). EU directive (2003/88/EC) requires a rest break after six hours of work.

57. Data from the focus group with workers from the publishing company, 3 and 6 June 2014.

58. Employment security means protection against arbitrary dismissal, work security means protection against accidents and illness at work, and income security means the assurance of an adequate stable income (BonNET Florence, Figueredo José B., STANDing Guy, "A Family of Decent Work Indexes," International Labour Review, vol. 142, nº 2, 2003, p. 213-238.).

59. It is worth stressing that the calculation of the Slovenian minimum wage is calibrated on the spending level of the country's poorest 20 per cent of households and, for this reason, does not establish a reliable absolute subsistence level. For the whole period since the crisis, the minimum wage has been set at a level that exposes recipients of the minimum wage to the risk of poverty.

60. This is also a very destructive force to solidarity among workers. Minimum-wage workers are forced to collaborate in breaking the legal, moral and solidarity principles that, in theory, protect them from exploitation.

61. International L ABOUR O RGANiSATION (ILO), Non-Standard Employment around the World: Understanding Challenges, Shaping Prospects, Geneva: ILO, 2016, p. 18.

62. The ratio of female workers was at 47 per cent in the paper factory.

63. Statistical significance for "age" is .001 . More than 90 per cent of employees aged 41 years or older are trade union members in comparison to 77 per cent of workers aged between 31 and 40 and 55 per cent of workers between 21 and 30 years. Statistical significance for "sex" is .001 (onesided) and statistical significance for "education" is .000 .

64. Statistical significances are .014 and .031 , respectively. More specifically, the trade union covers 67 per cent of female workers compared to 51 per cent of males.

65. Statistical significance is .000 .

66. Fisher's Exact Test one-sided statistical significance is .020 .

67. Analysing, for instance, the European Social Survey in TURNER Thomas, D'ART Daryl, "Public Perceptions of Trade Unions in Countries of the European Union: A Causal Analysis," Labour Studies Journal, vol. 37, $\mathrm{n}^{\circ}$ 1, 2012, p. 33-55, p. 50.

68. FREEMAN Richard B., Rogers Joel, What Workers Want, Ithaca, ILR Press, 2006; FREEMAN Richard B., BoXAll Peter, HAynes Peter (eds.), What Workers Say: Employee Voice in the Anglo-American Workplace, Ithaca, Cornell University Press, 2007; TURNER Thomas, D'ART Daryl, op. cit., p. 47-50. 
69. Additional factor analysis confirmed this interpretation. It showed two factors: the first was positively related to "improvement of working conditions," "solidarity aid," "legal assistance," and "wage increases," while the second factor was negatively related to "leisure activities," "holiday facilities" and "food bank." The first factor explained 39 per cent of the variance on measured variables, while the other factor 16 per cent. Together, they explained 55 per cent of the overall variability.

70. Statistical significances are .000 and .001 , respectively.

\section{ABSTRACTS}

The article examines the links between the evolution of the relationships of both labour/capital and trade unions/membership in post-socialist slovenia. Research was conducted in three Slovenian companies in the recession years 2013-2014. The presentation builds on the concept developed by the Italian Operaism of the "technical" and "political" composition of the labour force. The aim is to apprehend a range of employee positions in the workplace and how they impact political commitments, here expressed through choices concerning trade union membership and activities. The analysis helps us approach the contradictory situation found in the three companies in which all employees benefit from considerable exploitation of certain groups of production and service workers. Our research may be seen as a contribution to discussions and further research on the stratification of workers in a neoliberal context and on the challenges facing trade unions in the setting of growing poverty and precarity.

L'article examine les liens entre l'évolution des relations travail/capital et syndicats/membres dans la Slovénie post-socialiste. La recherche a été menée dans trois entreprises slovènes pendant les années de récession 2013-2014. L'analyse s'appuie sur le concept de composition « technique » et « politique » de la main-d'œuvre, développé par l'opéraïsme italien. L'objectif est d'appréhender divers positionnements des employés sur le lieu de travail et leur impact sur leurs engagements politiques, ici exprimés par des choix concernant l'adhésion et les activités syndicales. L'analyse de la composition technique et politique de la main-d'œuvre nous aide à aborder la situation contradictoire que l'on trouve dans les trois entreprises où l'ensemble des salariés tire avantage de la surexploitation spécifique de certains groupes de travailleurs de la production et des services. Notre étude peut être considérée comme une contribution aux discussions et aux recherches futures sur la stratification des travailleurs dans un contexte néolibéral et sur les défis auxquels les syndicats sont confrontés dans le contexte d'une pauvreté et d'une précarité croissantes.

\section{INDEX}

Geographical index: Slovénie

Keywords: post-socialism, Slovenia, stratification of workers, trade unions, labour aristocracy

Mots-clés: post-socialisme, Slovénie, stratification des travailleurs, syndicats, aristocratie ouvrière 


\section{AUTHORS}

\section{MAJA BREZNIK}

Mirovni inštitut, Ljubljana

maja.breznik[at]guest.arnes.si

\section{BORIS MANCE}

Social Communication Research Centre, Faculty of Social Sciences, University of Ljubljana boris.mance[at]fdv.uni-lj.si 